\title{
The Grammatical Structure of Discourse in The Notary Text
}

\author{
Dwi Purnanto \\ Universitas Sebelas Maret \\ Jl. Ir. Sutami, Surakarta, Indonesia \\ dwi.purnanto@yahoo.com
}

\author{
Sumarlam \\ Universitas Sebelas Maret \\ J1. Ir. Sutami, Surakarta, Indonesia \\ sumarlam@staff.uns.ac.id
}

\author{
Sutji Muljani \\ Universitas Sebelas Maret \\ Jl. Ir. Sutami, Surakarta, Indonesia \\ sutjimuljani70@gmail.com
}

\begin{abstract}
This study aims to (1) know, describe, and explain the grammatical structure of discourse in the notary text from aspects of the use of grammatical markers; (2) to describe the grammatical marker dominating the grammatical structure of discourse in the notary text; and (3) explain the characteristics of the notary text based on its grammatical structure. This research includes descriptive qualitative research. The research data in the form of writing data in the form of sentences and paragraphs. The research data was collected by reading notes technique. The data has been collected, then analyzed by distribution method (agih method) with the technique of Direct Element (PUL) as basic technique and advanced technique with top down technique. Based on the data obtained and the results of data analysis, this study shows that the grammatical structure of discourse in the notarial text is indicated by the use of grammatical discourse markers in the form of (1) reference, (2) substitution, (3) ellipsis, (4) conjunctions. The types of reference markers in the text of the notarization include (a) reference of endoophoric demonstrativa which is anaphoric and kataforis, (2) the endofora persona references which are anaphoric, and (3) the comparative references. The type of grammatical conjunction marker in the text of the notariat in the form of intersentence and intrasentence with the use of coordinative, subordinative and correlative conjunctions. The substitution marker in the notarial text of nominal, verbal, frasal, and clausal substitution. The deletion marker in the text of the notariat is subject matter deletion (S). Of the four markers of the grammatical structure of discourse in the notarial text, it is found that grammatical conjunction markers are used most often in the grammatical structure of notarial text resulting in the exploitation of conjunctions in their use. Conjunction exploitation becomes one of the characteristics of notarial text. Exploitation of excessive conjunctions makes the text of the notariat has a complex sentence structure so it is not easy for the lay reader to understand the content and meaning of the notary text easily.
\end{abstract}

Keywords - grammatical structure; discourse; notary text

\section{INTRODUCTION}

The state of Indonesia is a state of law. The statement is set forth in the Undang-Undang Dasar 1945 Constitution of the State of the Republic of Indonesia. As a constitutional state, the Government of Indonesia shall ensure the certainty, order and protection of the law to the people of truth and justice. To provide legal certainty and protection to the public, there is a need for evidence to clearly determine the rights and obligations of a person as a legal subject in society.

The strongest and most fulfilling evidence that has an important role in every legal relationship in the life of the community is an authentic deed. The need for authentication in the form of authentic deeds in legal relations in various fields, such as business, banking, land, social activities, etc. increase in line with the growing demand for legal certainty in various legal relationships, both at national, regional and global levels.

Officials authorized to make an authentic deed, that is notary. An authentic deed made by or before a notary not only because it is required by law but also because it is desired by an interested party.

Authentic deeds essentially contain formal truths as the parties notify the notary. The formal truths embodied in authentic deeds are manifested in the form of written texts which have their own characteristics in their use.

Legal articles and research in the field of law, including notarial deeds have been conducted by language experts and legal experts themselves. even books relating to legal language have been published. Nevertheless, many communities and legal practitioners still struggle to prosecute legal language, both in public legal products and private law products (civil law). This is because the language of the law, including the text of the notariat is often considered difficult to understand and the sentences are multiple interpretations so that there is often a difference of interpretation or interpretation among legal experts to a legal product.

In general, the study of linguistics in the field of law, in the form of articles, research results, and printed books, is more focused on the description and analysis of errors in the use of language in legal documents, the use of words, and the effectiviness of sentences in the language of the law, both in the letter of agreement and Sinal legislation (2013) in his dissertation entitled "Indonesian Law Law in a Legal 
Certain Perspective" concludes that (1) Indonesian law has a relationship with legal certainty; (2) The terminology, stewardship and writing of the Indonesian law shall be in accordance with the norms and rules of the Indonesian language that are true and good so that the meaning or concept contained in them is more easily understood. The findings of research in the field of legal texts by Sinal show the art of Indonesian language, especially the language arts in the text of the law must be based on Indonesian formal norms and rules because it will have an impact on the understanding of the law itself. However, in terms of linguistics research, these findings are still concerned with the effectiveness of sentences in the language of the law; have not leveraged linguistic theory in depth to peel legal language.

Similar findings of effectiveness in legal language are also found in (Kusuma research, 2010; Murniah, 2010; Fuad, 2007; Wijayanti, 2009; Mahadi and Ahmad 1979 in Sudjiman 1999; Matanggui, 2013 ; Attamimi, 1998). From the results of language studies on legal documents it can be seen that the Indonesian legal language in the letter of agreement, legislation, court decisions, and other legal documents still show a clichédise error, such as inaccuracy in the use of spelling, punctuation, ineffectiveness of the sentence, and the incoherence and incoherence of paragraphs. This means that legal language studies have not yet explored linguistic theories, including discourse theory. to review legal documents, including notarial texts.

In this research will be studied about the text of the notariat (ie authentic texts produced by or in front of a notary) based on the grammatical structure of discourse by using discourse analysis theory, especially written discourse analysis or text analysis.

Language unit can be regarded as a discourse if it has cohesion (form relation), coherence (meaning relation), and textual. Terms cohesion and coherence of discourse in forming a complete article can not be separated from the requirement of wholeness in forming sentences and paragraphs. That is, the accuracy of the use of grammatical structure markers and lexical structures in the discourse (in this case is notarial text) will support the formation of a neat discourse, both from the structure and understanding the meaning of the discourse. In other words, a unified discourse is a discourse which, when viewed in terms of the relationship of form or structure is cohesive; and seen in terms of relationship meaning or inner structure is coherent (Sumarlam, 2003, p. 23).

In relation to cohesion and coherence in the text, Halliday and Hasan (1976) divide cohesion into two types, namely grammatical cohesion and lexical cohesion. The grammatical aspects of discourse consist of (1) reference, (2) recovery / substitution, (3) ellipsis, (4) conjunctions. The lexical aspects of discourse include (1) repetition, (2) synonymy, (3) collocation, (4) hyponimi, (5) antonymy, (6) equivalence.

\section{LITERATURE REVIEW}

A. Discourse and Text

In connection with discourse and text, Edmundson, (1981, p. 4) states as follows. "A discourse is a structured event of manifest to linguistic (and other) behavior" (discourse is a structured event manifested in the behavior of language or other) and text a structured sequence of linguistic expressions forming a unitary whole is a set of structured language expressions forming a unity). Thus, discourse is a structured event expressed through language, while the text is a sequence of structured language statements (Sumarlam, 2003, p. 5).

In this regard, David Crystal in The Cambridge Encyclopedia of Language (1987, p. 116) distinguishes the concept between discourse analysis and text analysis, as follows.

"Discourse analysis focuses on the structure of
naturally occuring spoken language, as found in
such 'discourses' as conversations, interviews,
commentaries, and speech"; "text analysis focusses
on the structure of written language, as found in
such'text' as wssays, notices, road signs, and
chapters"

Discourse analysis can refer to the objective form of language exposure in the form of text (Aminudin, 1998, p. 4). Concerning the definition of text, Edmondson in Sumarlam (2003, p. 5) explains that "a text is a structured sequence of linguistics expressions forming a unitary whole". Thus, the text is a sequence of expressions or structured language statements that form a unity.

Language unit can be regarded as a discourse if it has cohesion (form relation), coherence (meaning relation), and textual. Terms cohesion and coherence of discourse in forming a complete article can not be separated from the requirement of wholeness in forming sentences and paragraphs. That is, the accuracy of the use of grammatical structure markers and lexical structures in the discourse (in this case is notarial text) will support the formation of a neat discourse, both from the structure and understanding the meaning of the discourse. In other words, a unified discourse is a discourse which, when viewed in terms of the relationship of form or structure of birth is cohesive; and seen in terms of relationship meaning or inner structure is coherent (Sumarlam, 2003, p. 23).

In relation to cohesion and coherence in the text, Halliday and Hasan (1976) divide cohesion into two types, namely grammatical cohesion and lexical cohesion. The grammatical aspects of discourse consist of (1) reference, (2) recovery/substitution, (3) ellipsis, (4) conjunctions. The lexical aspects of discourse include (1) repetition, (2) synonymy, (3) collocation, (4) hyponimi, (5) antonymy, (6) equivalence.

In addition to the structure, discourse analysis also relates to the function of language in its use. Discourse analysis can not be limited only to descriptions of language forms or language structures separate from the purpose and function of language designed to use the form in the process of human interaction (Brown and Yule, 1983). Discourse analysis seeks answers to the function and usefulness of language by humans. 


\section{B. Grammatical Structure of Text}

The grammatical structure of the text is the structure of the form or structure of the text which is characterized by the use of grammatical aspects to show a cohesive relationship. Grammatical aspects of a written or text discourse (Sumarlam, 2003, p. 23) include (1) reference, (2) substitution, (3) ellipsis, (4) conjuction.

\section{1) Reference}

Reference is one type of grammatical cohesion in the form of a particular lingual unit referring to another lingual unit (or reference unit) that precedes or follows it (Sumarlam, 2003, p. 23). Based on the place you are in, the reference is divided into endofores and exophora. Endophora, which is the reference that occurs when the lingual unit referred to is in the text. Exsophora, which is a reference that occurs when the unit is outside the text of the discourse.

Endofora consists of anaphora and katafora. Here is an example of endophora and exophora. Anafora reference is a grammatical cohesion in the form of a certain lingual unit that refers to other lingual units that precede it; or refer to the antecedents on the left; or referring to the other called elements. The reference of exophora is an endoophorous reference in the form of a specific lingual unit referring to other lingual units following it; or referring to the antecedents on the right; or referring to the elements mentioned later.

Reaction cohesion consists of (1) persona reference, (2) demonstrative reference, and (3) comparative reference. Persona reference are realized by the use of pronouns persona (person pronouns), both singular and plural first persona, singular and plural second persona, and singular and plural third persona. The first single person marker covers aku (I), saya, hamba, gua/gue, ana/ane, atau ku(me). The first person plural marker covers kami (we), kami semua (we all), kita (all of us). The second single person marker covers kamu (you), engkau, Anda, entelanta, kau(yours), -mu, elu/elo. The multiple persona marker covers kати sетиа, kalian, kalian sетиа. The third person person marker includes ia (he), dia, beliau, di-, -nya ( him or her, third personality marker covers mereka (they) dan mereka semua (all of them)

\section{2) Recovery (substitution)}

Recovery, which is one type of grammatical cohesion in the form of replacement of a particular lingual unit (which has been called) with other lingual units in the discourse to obtain the distinguishing element. Substitution markers, based on their lingual units, are divided into nominal recovery, verbal recovery, frasal recovery, and clause recovery.

Nominal recovery, ie recovery of lingual units categorized nouns with other lingual units also categorized nouns. Verbal recovery, ie recovery of lingual units categorized verbs with other lingual units also categorized as verbs. Recovery of the frasal, ie the restoration of lingual units of words or phrasa with other lingual units in the form of phrases. Clause recovery, ie recovery of certain lingual units in the form of clauses or sentences with other lingual units in the form of words or phrases.

\section{a) Destruction (ellipsis)}

Elipsis which is one type of grammatical cohesion in the form of removal or exposure of certain lingual units mentioned previously. Lingual units that can be passed can be words, phrases, clauses, and sentences. Grammatical grammatical markers are used grammatically in notarial text to achieve the effectiveness and efficiency of sentences and to achieve sentence congruence.

b) Conjuction

A series is one type of grammatical cohesion done by assembling one element with another in the sentence. elements that are coupled can be words, phrases, clauses, sentences, even paragraphs. The sequence marker can be a series of intrasentence, intersemtence sequences, correlative sequences. Inside the intrasentence conjunction there are coordinative conjunctions and subordinate conjunctions. The intrasentence conjunction operates within the sentence level.

The intrasentence conjunction expresses the following meaning relationship.

1) Additive relations: dan (and), bersama (together), serta, besertar

2) Adversative relations: tetapi (but), tapi, melainkan (rather)

3) Alternative relations: atau (or), ataukah

4) Cause relations: sebab (cause), karena, lantaran, gara-gara0cause of)

5) Result relations: hasilnya (the result), akibat (consequently), akibatnya (the result)

6) Purpose relations: untuk (for), agar (order), demi (for), supaya (sake)

7) Terms relations: asalkan (as long as), jika (if), jikalau, kalau

8) Time relations: sejak, sedari, ketika, sewaktu (when), waktu, saat (time), tatkala (moment), selagi (while), selama, seraya (during), setelah (after), sesudah, seusai (so), begitu (while), hingga (through)

9) Concencive relations: sungguhpun (eventhough), biarpun (though), meskipun, walaupun, sekalipun, kendatipun, betapapun.

10) Way relations: tanpa (without), dengan (with)

11) Reality relations: bahwa (that)

12) Tool ralations: dengan (with), tidak dengan ( not by), memakai (wearing), menggunakan (using), mengenakan (wearing), memerantikan (tuning)

13) Equative relations: sebanyak (as much), seluas (width), selebar (width), sekaya (richness)

14) Comparative relations: lebih dari (more than), kurang dari (less than), lebih sedikit daripada ( less than), lebih banyak daripada (more than)

15) Output relations: sampai (until), sehingga (so), maka (then), sampai-sampai

16) Restrictive attributive relations: yang (which)

17) Attributive nonattributive relations: yang (which) (usually begins with a comma)

18) Constituency relations: andaikata (if), seandainya (suppose), andaikan, kalau saja (if only), jika saja, 
jikalau, jika, bilamana, apabila, dalam hal (in case), jangan-jangan (lest), kalau-kalau(in case)

19) Optaive relations: mudah-mudahan (hopefully), moga-moga, semoga, agar (so)

An interclause conjunction operates at a level outside the sentence. Interclause conjunctions have the following relation of meaning.

1) Relations of the meaning of contradiction: biarpun begitu, biarpun demikian, sekalipun demikian, sekalipun begitu, walaupun demikian, walaupun begitu, meskipun demikian, meskipun begitu, sungguhpun demikian, sungguhpun begitu, namun, akan tetapi

2) Relations of continuity meaning: sesudah itu (after that), setelah itu, selanjutnya (then), kemudian

3) Relations of meaning there are events, things, circumstances beyond the stated; tambahan pula (additionally), lagipula (besides), selain itu (besides)

4) Relations of opposite meanings: sebaliknya (on the contrary), berbeda dari itu (different from that), kebalikannya (the opposite)

5) Relations of the meaning of reality: sesungguhnya, bahwasanya, sebenarnya (in fact)

6) Relations of meaning that reinforces the situation: malah (in fact), malahan (in fact), bahkan (even)

7) Relations of meaning that states exclusiveness and inclusiveness: kecuali itu (except that)

8) Relations of consequences: dengan demikian (thus)

9) Relations of meaning that states the event that precedes the previously stated: sebelum itu (before that).

Correlative conjunction, which is a conjunction consisting of two elements used in pairs. The marker of correlative conjunctions, such as antara...dan ,between ... and), dari...hingga (from ... to), dari...sampai dengan, dari...sampai ke, dari...sampai, dari...ke, baik...maupun (neither ... nor), tidak hanya...tetapi juga (not only ... but also), bukan hanya....melainkan juga, demikian...sehingga (in a way ... that), sedemikian rupa...sehingga, apakah...atau (whether ... or), entah...entah (somehow ... either), jangankan...pun (let...alone).

\section{METHOD}

The study of the Grammatical Structure of Discourse in Notary Text is an analytical descriptive study with the support of qualitative data. The case study approach (case study) was used in this study. The results of research on the grammatical structure of discourse in the text of the notariat can be used to provide an early description of the grammatical identification of the grammatical structure of language in other legal documents, although it must be aware of differences due to the values in different contexts (Riyadi, 2014). The case study approach in this study can also be used to explain why documents in the form of notarial text have a grammatical structure as analyzed.
This study uses primary and secondary sources. Primary sources are notarial text in the form of Akta Surat Kuasa (Deed of Power of Attorney), Akta Jual Beli (Deed of Buying Juice), and Akta Pendirian Yayasan (Foundation Deed of Establishment). Secondary sources are obtained from previous research results and from various relevant literature. The research data was collected by using library technique and technique of record.

Data were analyzed by using the agih method with technique for direct element as its basic technique. The next step, the data were analyzed by addition technique, change technique, and technique of ellipsis as the advanced technique.

All data collected through the above techniques will then be sorted and selected, classified and linked or accumulated among the data to one another. In addition, all data will also be linked between the primary source and the sources of the library or secondary sources as a form of interpretation. Furthermore, the data will be synthesized in order to develop a model of grammatical structure of discourse in the applicable notarial text.

\section{RESULT AND DISCUSSION}

Based on the results of data analysis, it is known that the grammatical structure of the notarized text is marked by the use of grammatical markers or markers which includes the reference and the series. Grammatical reference marker were dominated by demonstratifa demonstrative and personal reference.

The use of grammatical markers on notary text is shown in table 1 below.

TABLE I. GRAMMATICAL MARKERS TYPE IN ASK, AJB, AND APY

\begin{tabular}{|c|c|c|c|c|c|}
\hline \multirow[t]{2}{*}{ No. } & \multicolumn{4}{|c|}{ Type of grammatical marker } & \multirow{2}{*}{$\begin{array}{c}\text { Keteranga } \\
n\end{array}$} \\
\hline & Reference & Cunjunction & $\begin{array}{l}\text { Substitu } \\
\text { tion }\end{array}$ & $\begin{array}{c}\text { Ellips } \\
\text { is }\end{array}$ & \\
\hline 1 & 3 & 4 & 5 & 6 & 7 \\
\hline & $\begin{array}{l}\text { 1. A } \\
\text { Persona } \\
\text { single } \\
\text { O1 that } \\
\text { refers } \\
\text { to the } \\
\text { name of } \\
\text { self } \\
\text { 2. A } \\
\text { single } \\
\text { O3 } \\
\text { Persona } \\
\text { referrin } \\
\text { g to the } \\
\text { plural } \\
\text { Demon } \\
\text { stration } \\
\text { of } \\
\text { demons } \\
\text { trativa } \\
\text { ini pada } \\
\text { frasa } \\
\text { hari ini } \\
\text { Compar } \\
\text { ative } \\
\text { referen } \\
\text { ce } \\
\text { (sebaga }\end{array}$ & 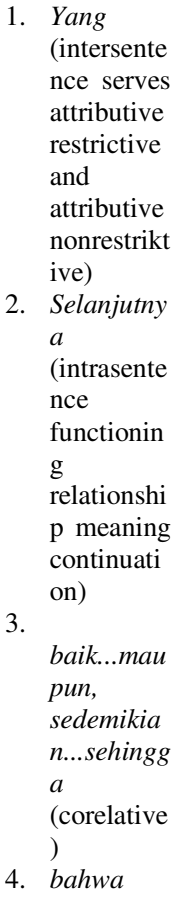 & $\begin{array}{l}\text { Substit } \\
\text { ution } \\
\text { clause }\end{array}$ & $\begin{array}{l}\text { Ellips } \\
\text { is } \\
\text { Subje } \\
\text { ct } \\
\text { (S), } \\
\text { Adve } \\
\text { rbial } \\
\text { (Ket) }\end{array}$ & $\begin{array}{l}\text { Grammat } \\
\text { ical } \\
\text { markers } \\
\text { dominate } \\
\text { grammati } \\
\text { cal } \\
\text { structures } \\
\text { in } \\
\text { notarial } \\
\text { text } \\
\text { resulting } \\
\text { in } \\
\text { conjuncti } \\
\text { onal } \\
\text { exploitati } \\
\text { on, such } \\
\text { as the use } \\
\text { of the } \\
\text { following } \\
\text { conjuncti } \\
\text { on } \\
\text { markers: } \\
\text { 1. Untuk } \\
\quad \text { dan } \\
\text { atas } \\
\text { nama, } \\
\text { 2. demik }\end{array}$ \\
\hline
\end{tabular}




\begin{tabular}{|c|c|c|}
\hline i) & $\begin{array}{l}\text { (intersente } \\
\text { nce } \\
\text { expressed } \\
\text { the } \\
\text { relationshi } \\
\mathrm{p} \text { of } \\
\text { meaning } \\
\text { of reality) } \\
\text { 5. atau } \\
\text { (intersente } \\
\text { nce } \\
\text { relationshi } \\
\text { p meaning } \\
\text { of } \\
\text { election) } \\
\text { 6. serta, } \\
\text { beserta } \\
\text { dengan } \\
\text { (intersente } \\
\text { nce } \\
\text { relations } \\
\text { of additive } \\
\text { meaning) } \\
\text { 7. sedangkan } \\
\text { 8. maka } \\
\text { 9. kecuali } \\
\text { 10. sebagai } \\
\text { berikut }\end{array}$ & $\begin{array}{l}\text { ian } \\
\text { besert } \\
\text { a } \\
\text { denga } \\
\text { n, } \\
\text { 3. dan } \\
\text { turut } \\
\text { serta } \\
\text { 4. dan } \\
\text { selanj } \\
\text { utnya } \\
\text { 5. apa } \\
\text { yang } \\
\text { 6. sedem } \\
\text { ikian } \\
\text { rupa } \\
\text { sehing } \\
\text { ga } \\
\text { 7. oleh } \\
\text { sebab } \\
\text { karena } \\
\text { 8. dan } \\
\text { karena } \\
\text { nya } \\
\text { 9. dan } \\
\text { setela } \\
\text { h } \\
\text { 10. dan } \\
\text { jika, } \\
\text { 11. juga } \\
\text { dan, } \\
\text { 12. oleh } \\
\text { dan } \\
\text { dari } \\
\text { 13. seba } \\
\text { gaima } \\
\text { na } \\
\text { dimak } \\
\text { sud } \\
\text { 14. seba } \\
\text { gaima } \\
\text { na } \\
\text { yang } \\
\text { dimak } \\
\text { sud }\end{array}$ \\
\hline
\end{tabular}

The grammatical structure of a discourse is a structure of text characterized by the use of cohesion markers and grammatical coherence so as to achieve a cohesive and coherent text grammatically. The marker of the grammatical structure of the text includes (1) reference, (2) substitution, (3) ellipsis, (4) conjunctions.

The following data shows the use of grammatical marker triggers demonstrativa in the structure of notarial text.

(1) Pada hari ini Jumat, tanggal 26-02-2016 (duapuluh enam Februari duaribu enambelas) 13.00 WIB (pukul tiga belas Waktu Indonesia Bagian Barat), ....(02/ASK 1/II/2016/1) (Pengacuan demonstratifa endofora yang bersifat kataforis)

(2) Pada hari ini, Selasa, tanggal 20 (dua puluh) bulan Desember tahun 2005 (duaribu lima)--- (15/AJB 1/XII/2005/1)
In the phrases (1) and (2) the phrase hari ini (today) is demonstrative referencing time referring to other elements contained in the text mentioned later, ie the words of Jumat (Friday) in sentence (1) and the word Selasa (Tuesday) in sentence (2). With such characteristics, the phrase of hari ini (today) in (1) and (2) is a type of grammatical cohesion of demonstrative endophores (due to its reference in text) which is cataphores (because its antecedents are on the right) through a lingual unit of a demonstrative phrase.The following data indicates the use of the personal reference marker.

(3) Hadir di hadapan saya, JEFRI OKTA WIJAYA, Sarjana Hukum, Magister Kenotariatan, Notaris di Kabupaten Sukoharjo, (03/ASK 1/II/2016/1)

(4) ....hadir di hadapan saya PURNAMANINGRUM, Sarjana Hukum yang berdasarkan surat Keputusan Menteri Negara Agraria/Kepala Badan Pertanahan Nasional, tanggal 13-3-1998, nomor 15-XI-1992, diangkat sebagai Pejabat Pembuat Akta Tanah yang selanjutnya disebut PPAT yang dimaksud dalam pasal 7 Peraturan Pemerintah Nomor 24 Tahun 1997 tentang Pendaftaran Tanah, sengan daerah kerja seluruh Kabupaten Sukoharjo, dan berkantor di jalan Solobaru AB 02 Solobaru Sukoharjo .... (16/AJB 1/XII/2005/1)

Saya on (3) and (4) are pronominal persona references which refer to other elements in the later-mentioned text, namely JEFRI OKTA WIJAYA, Sarjana Hukum, Magister Kenotariatan, Notaris , .... (3) and PURNAMANINGRUM, Sarjana Hukum (4). With that characteristic, saya on (3) is a type of grammatical cohesion of the pronounced endophoric persona (because its reference is in the text) which is a cataphoric (because its antecedents are on the right) through a lingual unit of the first single person

(5) ...dengan dihadiri oleh para saksi Akta, yang namanamanya akan disebut pada bagian akhir akta ini:... (04/ASK 1/II/2016/1)

The data in (5) shows the use of grammatical and coherent grammatical cohesion markers. The use of reference to such data, ie the reference to the plurality of third persons, that is -nya and demonstrative reference to ini on the phrase ...pada bagian akhir akta ini. The series markers on the (5) are shown by the use of conjunctions yang.

The form -nya in (5) is a single third persona pronoun referring to another element contained in the text already mentioned, namely the words of para saksi containing plural meanings. This characteristic, the form -nya in (5), is a grammatical cohesion of the endofora referral persona (because its reference is in text) is anaphoric (because its antecedents are on the left) through a lingual unit of enclitic - nya.

In the case of legal language in the text of the notarization, the third person's singular pronoun -nya refer to the plural, namely the phrase of para saksi. It becomes one of the characteristics of the use of legal language, especially the text of the notariat. 
In sentence (5) it is also shown that the use of demonstrative demonstration ini refers to another element contained outside the text, which is Akta Surat Kuasa (ASK) as a referent in the form of a legal written document. Thus, the form ini at (5) is an exophora demonstrative reference (because of its out-of-text referent) that anaphoric reference (because anonymous reference) through a written legal reference.

In addition to persona and demonstrative references, sentence (5) also indicates the use of grammatical markers in the form of conjunctions yang as a subordinate clause link. The first clause, that is ...dihadiri oleh para saksi Akta, and the second clause, namely ...nama-namanya akan disebut pada bagian akhir akta ini:.. linked into multi-tiered sentences with conjunctive markers indicating the meaning of affirmation.

The following data shows the use of substitutions, either nominal substitution, verbal, frasal, or clausal. The use of various grammatical substitution markers in the following data shows the characteristics of legal language, especially notarial text.

(6) Tuan PURWONO, lahir di Sukoharjo pada tanggal 1008-1983---(sepuluh Agustus seribu sembilanratus delapan puluh tiga), -----------Karyrawan Swasta, Warga Negara Indonesia, bertempat tinggal di------Norowangsan, Rukun Tetangga 005, Rukun Warga 013-----------------Kelurahan/Desa Pajang, Kecamatan Laweyan, Kota Surakarta-----------Pemegang Kartu Tanda Penduduk dengan Nomor Induk-----------------Kependudukan: 3372011008830002------------------------------------------yang

dalam melakukan perbuatan hukum pada akta ini telah mendapat persetujuan dari isterinya, yaitu: Nyonya DESI RIPTINI, lahir di Sukoharjo, pada tanggal 21-12-1981 (duapuluh satu Desember seribu sembilan ratus delapanpuluh satu), Warga Negara Indonesia, bertempat tinggal yang sama dengan suaminya tersebut diatas, yang turut pula berhadapan dengan saya, Notaris dan ikut menandatangani akta ini,----Pemegang Kartu Tanda Penduduk dengan Nomor Induk Kependudukan: 3372016112810002--------------------------Yang keduanya pada saat ini berada di Kabupaten Sukoharjo------------Para penghadap selanjutnya disebut sebagai-PEMBERI KUASA ..(05/ASK 1/II/2016/1)

The data in sentence (6) indicates the use of marking markers, sequence markers, and change markers. The reference markers used in (6), namely personal reference and comparative reference. The single person's -nya persono's reference to ....persetujuan istrinya... is used to refer to the lingual unit in front of him contained in the text, namely Mr. Sarwono. The antecedents referred to by him, namely Tuan Sarwono is in front of his form. The antecedents referred to by -nya, namely Tuan Sarwono is in front of -nya form. Based on such characteristics, the personality reference marker is ananaphoric endofora reference. Prognostic endoophoric pronouns also appear in (6). The reference appears in the use of saya as a single person pronoun of personality which refers to a notary word located behind saya word.

In addition to using a personal reference marker, the comparative reference is also used in sentences (6). The use of words sebagai indicating the comparison between two names with a clear identity with their status as Authorizer in ASK.

Sentence (6) shows the use of clause substitution markers, ie substitution of certain lingual units in the form of words or phrases. The statement on (6) which started from Tuan Purwono ........ s.d. Sukoharjo is a lingual unit in the form of a sentence. The sentence is substituted as Pemberi Kuasa in the next statement, namely Para penghadap selanjutnya disebut sebagai----PEMBERI KUASA. Lingual Unit of Pemberi Kuasa in the form of a phrase to replace lingual units in sentence form. Based on such characteristics, the data in (6) shows the use of grammatical markers of clausal substitution.

The sentence Para penghadap selanjutnya disebut sebagai---PEMBERI KUASA--- at (6) denotes the use of grammatical sequential markers, ie selanjutnya word. By the use of conjunctions, the word selanjutnya is an intercostal phrase that serves to show the meaning of the continuation of the sentence expressed in the previous sentence. As the interconnection link, the next hyphen is used at the beginning of the sentence. However, in the context of legal language, in this case is the text of the notariat, the hyphen selanjutnya is used unlike its function as an relations beetween sentence, because it is placed after the subject of the sentence, so the sentence becomes as follows. Para penghadap selanjutnya disebut sebagai Pemberi Kuasa, bukan Selanjutnya, para penghadap disebut sebagai Pemberi Kuasa.

Based on the context with the preceding statement, conjunction selanjutnya to (6) not only serves as a relations between sentence, but also serves as an affirmation of the status of Para Penghadap as the phenomenon of use and the subsequent hyphen function becomes the characteristic of the legal language, especially the text of the notary.

Grammatical reference of the series with the marker also coloring the data at (6). The use of the sequence marker shown in (6) appears in the following sentence (6) a s.d.d.

(6)a. Tuan PURWONO, lahir di Sukoharjo pada tanggal 10-08-1983...yang dalam melakukan perbuatan hukum pada akta ini telah-mendapat persetujuan dari isterinya, yaitu: ...

(6)b. bertempat tinggal yang sama dengan suaminya tersebut diatas

(6)c. ...., yang turut pula berhadapan dengan saya,...

(6)d. Yang keduanya pada saat ini berada di

Kabupaten Sukoharjo------

The conjunction marker yang at (6) a s.d. d represents the intrasentence sequence marker. The linking of yang in (6) a and b means a restrictive attributive relationship, namely the explanatory constraint, while at (6) $\mathrm{c}$ and $\mathrm{d}$ 
means attributive attribute is notrestrictive, that is, the noninvasive explanatory relationship.

The ellipsis marker is present in the data in the following sentence (7).

\section{(7) Selanjutnya disebut sebagai}

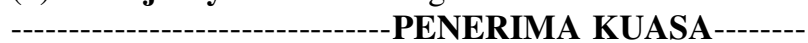 $(06 / \mathrm{ASK} 1 / \mathrm{II} / 2016 / 2)$}

The data in the statement (7) indicates the use of grammatical markers of conjungtion and ellipsis. The grammatical conjunction marker is present in the use of conjunction between sentences, namely selanjutnya which serves to show the meaning of the continuation of the sentence expressed in the previous sentence. The imprint contained in the data in the statement (7), ie the subject deletion $(\mathrm{S})$.

The interesting part of the grammatical structure in the notarial text, namely the use of grammatical markers of different series of functions simultaneously and sequentially in a single statement. This is shown in the following data.

(8) melepaskan hak atas : Sebidang tanah Hak Milik Nomor:4128/Gampang yang diuraikan dalam Surat Ukur tanggal;17/11/2007,Nomor: 00254/2007, seluas 72 M2(tujuhpuluh dua meter persegi) terletak di: Propinsi

: Jawa Tengah--------Kabupaten :
Sukoharjo--------Kecamatan : Kartasura------------------Demikian beserta dengan tanaman serta hasil karya yang telah ada atau akan ada yang merupakan satu kesatuan dengan tanah tersebut,-(07/ASK 1/II/2016/2 s.d. 3)

The statement in (8) uses many conjunction markers, ie untuk dan, dan, yang, demikian beserta dengan, serta, atau. Kata untuk dan kata dan dalam in (8) are two different functional conjunctions, but are used together and sequentially. The grammatical sequential marker untuk functioning states the relationship of purpose, whereas dan serves to express the additive relationship (sum). In addition to the use of grammatical sequential markers. Based on the context of the sentence, in sentence (8) there is also an omission of Pemberi Kuasa which serves as a benefactive description. It can be observed on the following data splinter.

(8)a.Untuk PEMBERI KUASA menjual, mengalihkan, memindahtangankan dan melepaskan hak atas : Sebidang tanah Hak Milik Nomor:....

(8)b. Atas nama PEMBERI KUASA menjual, mengalihkan, memindahtangankan dan melepaskan hak atas : Sebidang tanah Hak Milik Nomor:....

The use of two grammatical substitution / replacement markers and the addition chord sequence appear at the following data splinter. (8)c. Demikian beserta dengan tanaman serta hasil karya yang telah ada atau akan ada yang merupakan satu kesatuan dengan tanah tersebut.

Sentence (8) c denotes the use of grammatical markers of dengan demikian clause substitution and the sequence markers beserta dengan. Substitution of clause, ie the replacement of certain lingual units in the form of clauses or sentences with other lingual units in the form of words or phrases. The word Demikian at (8) c replaces the previous sentence in (8).

(9) Untuk mencapainya maksud tersebut diatas, maka yang diberi kuasa berhak antara lain menghadap dimana perlu, kepada lembaga/instansi baik pemerintah maupun swasta khususnya kepada Pejabat Pembuat akta Tanah memberikan segala surat-surat, bukti-bukti dan kelengkapan-kelengkapan, melakukan segala perjanjian dan perikatan yang diperlukan menentukan dan turut serta segala persyaratan dan selanjutnya menyerahkan apa yang dijual/dialihkan/dilepaskan itu kepada pembelinya/penerima haknya, menerima uang hasil penjualannya, memberikan tanda bukti penerimaan uang/kwitansinya yang sah dan sempurna,menandatangani segala akta/formulir/isi-isian, mengajukan surat-surat permohonan-permohonan melakukan penyerahan, melengkapi segala ketentuan dan persyaratannya yang diperlukan/diharuskan sedemikian rupa sehingga urusan tersebut selesai dengan sebaik-baiknya, dan secara sempurna (08/ASK $1 / \mathrm{II} / 2016 / 3$ )

The statement in (9) shows the use of the various grammatical sequential markers, ie, untuk, maka yang, dimana, baik .....maupun, khususnya, dan, yang, dan turut serta, dan selanjutnya, apa yang, sedemikian rupa sehingga. The conjunction marker untuk declare the allotment relationship. The use of the conjunction marker maka yang on (9) has its own function. The marker maka states a causal relationship, whereas the marker yang at (9) expresses the affirmation relationship to the power of the power of attorney, rather expresses the attributive attribute of restrictive or attributive nonrestrictive. The conjunction marker dan selanjutnya at (9) show the exploitation of conjunction selanjutnya. The conjunction selanjutnya is an intercostal conjunction that shows a continuation relationship. However, in (9) the conjunction selanjutnya is further exploited into an intrasentence conjunction coupled with an additive conjunction dan becomes dan selanjutnya expresses the additive relationship. The phrase di mana the Indonesian rule serves as a question word, not functioning as a conjunction. However, in the statement (9) the phrase $d i$ mana it functions as a conjunction stating the relationship terms. In Indonesian language rules are used if the conjunction marker, jika, bila, apabila, jikalau, kalau. The exploit of a question word di mana as a conjunction in the statement (9) is influenced by the structure of the English language which can function as a conjunction, in addition to functioning as a questionword. Thus, in the context of the 
use of di mana as a conjunction in the statement (9) may be substituted by conjunction jika.

In addition to subordinate and coordinative conjunction markers, the statement (9) also shows the use of correlative conjunction markers baik ... maupun. Correlative conjunction, which is a conjunction consisting of two elements used in pairs. Paired forms like that are idiomatic so can not be modified just like that (Rahardi, 2010: 114). The use of correlative conjunctions also appears in the use of conjunctions sedemikian rupa sehingga that they are idiomatic.

Conjunction exploitation also occurs in combining the use of conjunction markers which express the additive relationship, that is, dan turut serta. The use of the conjunction of the conjunction marker is intended to affirm the meaning of the statement.

The use of grammatical sequential grammatical markers with varying meanings of relationships in statements (9) suggests the exploitation of conjunctions in the legal language, in this case, the text of the notarization. It becomes another characteristic of legal language.

Conjunction exploitation is also shown in the following (10) and (11) statements.

(10) Para pihak dan atau penghadap menyatakan dengan ini menjamin akan------kebenaran identitas para pihak dan atau penghadap sesuai tanda pengenal---yang disampaikan kepada saya, Notaris, dan bertanggung jawab sepenuhnya atas hal tersebut dan selanjutnya para pihak dan atau penghadap juga menyatakan telah mengerti dan memahami isi akta ini(11/ASK 1/II/2016/3 s.d 4)

The conjunction dan atau at (10) markers are two distinct types of markers in sentences, but are used sequentially and simultaneously in the text of the notarization. Markers dan show the relationship of alternative meanings, while atau show the relationship of choice meanings. The use of conjunctive dan atau concurrent dan atau consecutive and sequential markers in legal languages are grammatically structured in between two different sentences two subjects and have different legal interests. The subject of para pihak and para penghadap of different legal status and interests. The subject of para pihak and the subject of para penghadap may jointly guarantee the truth of the deed; or it could be one of the subjects that guaranteed the truth of the deed.

(11) Dalam hal yayasan oleh karena sebab apapun tidak mempunyai anggota Pembina, maka dalam waktu 30 (tiga puluh) hari sejak terjadinya kekosongan tersebut wajib diangkat anggota Pembina berdasarkan keputusan rapat gabungan anggota Pengawas dan anggota Pengurus.

The exploitation of the conjunction in the statement (11) appears in the use of inter conjunction markers oleh karena it is used in conjunction with the intrasentence conjunction marker oleh karena in a serial arrangement. As an intersentence conjunction, the marker oleh karena must initiate the sentence. However, the conjunction marker oleh karena on (11) is exploited as an intrasentence conjunction which should be the link between the clause, not the intersentence links.

In addition to the exploitation of conjunctions, the statement at (11) also shows the lexical structure of repetition for anggota pembina phrases. The repetition includes repetition/repetition epizeukis.

\section{CONCLUSION}

The grammatical structure of the grammatical cohesion markers, namely grammatical conjungtion markers, grammatical substitution markers, grammatical addition markers, grammatical ellipsis markers. Grammatical conjunction markers are most commonly used in notarial text structures resulting in the exploitation of conjunctions in their use. Conjunction exploitation becomes one of the characteristics of legal language, including notarial text.

The grammatical structure of discourse in the text of the notariat appears to be seen in the use of grammatical cohesion markers, namely grammatical conjunction markers, grammatical substitution markers, grammatical addition markers, grammatical ellipsis markers. Grammatical conjunction markers are most commonly used in notarial text structures resulting in the exploitation of conjunctions in their use. Conjunction exploitation becomes one of the characteristics of legal language, including notarial text.

\section{References}

Aminuddin. (1989). Analisis wacana dan telaah karya sastra. Dalam Puitika. Edisi 01/th.1/1989. Malang: HISKI.

Brown, Gillian dan George Yule. (1996). Analisis wacana (diterjemahkan oleh I. Soetikno dari Discourse analysis). Jakarta: Gramedia Pustaka Utama.

Dardjowidjojo, Soenjono. (1986). Benang pengikat wacana, dalam Pusparagam linguistik dan pengajaran bahasa (disunting oleh Bambang Kaswanti Purwo). Jakarta: Unika Atmajaya.

Djajasudarma, Fatimah. (2006). Metode lingusitik: ancangan metode penelitian dan kajian. Bandung: Adhitama.

Djatmika. (2014). Perilaku bahasa dalam surat perjanjian: kajian lingusitik sistemik fungsional. Surakarta: UNS Press.

Kesuma, Tri Mastoyo jati. (2010). Bahasa Indonesia hukum: karakteristik dan permasalahannya. Dalam Prosiding Seminar Internasional dalam rangka PIBSI XXXII. Universitas Widya Dharma Klaten.

Mahsun. (2012). Metode penelitian bahasa: tahapan strategi, metode, dan tekniknya. Jakarta: Grafindo.

Matanggui, Junaiyah H. (2013). Bahasa Indonesia untuk bidang hukum dan peraturan perundang-undangan. Jakarta: Grasindo.

Rahardi, Kunjana. (2013). Bahasa Indonesia untuk perguruan tinggi. Jakarta: Erlangga. 
Sudaryanto. (2015). Metode dan aneka teknik analisis bahasa. Klaten: Sanata Dharma University Press.

Sumarlam, dkk. (2003). Teori dan praktik analisis wacana. Surakarta: Pustaka Cakra

Sinal, Mohammad. (2013). Bahasa Indonesia hukum dalam perspektif kepastian hukum (Disertasi). Fakultas Hukum. Universitas Brawijaya.

Wijayanti, Sri Hapsari. (2012). Bahasa hukum Indonesia dalam surat perjanjian. Retrieved from (http://www.atmajaya.ac.id/web/KontenUnit.aspx?gid= artikel-hki\&ou=hki\&cid=artikel-hki-bahasa-hukumindonesia) 